\title{
Early ontogenetic growth stages of Middle Ordovician orthoceratoid cephalopods from Bohemia
}

Martina Aubrechtová, Vojtěch Turek, and Ondřej Zicha

Acta Palaeontologica Polonica 65 (3), 2020: 575-588 doi:https://doi.org/10.4202/app.00721.2020

This study describes 18 specimens representing the earliest growth parts of orthoceratoid cephalopods, most of which have been recently obtained from the Middle Ordovician strata of the Prague Basin, central Bohemia. Only about 20 specimens of Ordovician orthoceratoids displaying embryonic shell are known globally and the Bohemian material thus significantly expands their current record. The studied collection includes twelve specimens assigned to the species Bactroceras sandbergeri and shows that the morphological variability in early ontogenetic growth stages of this species was rather low. The absence of a cicatrix was definitely confirmed in this phylogenetically important cephalopod. Six other specimens investigated herein are indeterminate orthoceratids. Initial chambers, where preserved, are generally large compared to known, stratigraphically younger specimens. This is interpreted here as supporting the previously postulated trend of decreasing the egg- and hatchling sizes in orthoceratoid cephalopods from mid-Ordovician times onwards. Alternatively, the large sizes of these Bohemian orthoceratids may be explained by the position of the Prague Basin in relatively cool-water high palaeolatitudes during the Middle Ordovician.

Key words: Cephalopoda, Orthoceratida, early ontogeny, embryonic shell, Paleozoic, Darriwilian, Bohemia, Czech Republic.

Martina Aubrechtová [aubrechm@gmail.com], Institute of Geology and Palaeontology, Faculty of Science, Charles University in Prague, Albertov 6, 12843 Praha 2, Czech Republic; Institute of Geology of the Czech Academy of Sciences, Rozvojová 269, 165 00, Prague 6-Lysolaje, Czech Republic. Vojtěch Turek [vojtech.turek@nm.cz], National Museum Prague, Václavské náměstí 68, 11579 Praha 1, Czech Republic. Ondřej Zicha [ondrej.zicha@gmail.com], BioLib, z. s., Jugoslávských partyzánů 34, 160 00, Praha 6, Czech Republic.

This is an open-access article distributed under the terms of the Creative Commons 
Attribution License (for details please see creativecommons.org), which permits unrestricted use, distribution, and reproduction in any medium, provided the original author and source are credited.

For 